\title{
Effect of Recombination on Series Resistance in eta Solar Cell Modified with In(OH)xSy Buffer Layer
}

\author{
Robinson Musembi ${ }^{1, *}$, Be rnard Aduda ${ }^{1}$, Julius Mwabora ${ }^{1}$, Marin Rus u ${ }^{2}$, Kons tantinos Fostiropoulos ${ }^{2}$, \\ Martha Lux-Steiner ${ }^{2}$ \\ ${ }^{1}$ Department of Phy sics, University of Nairobi, Nairobi, P.O. Box 30197-00100, Kenya \\ ${ }^{2}$ Helmholtz-Zentrum Berlin fur Materialen und Energie, Lise Meitner Campus, Glienicker Strasse 100, 14109, Berlin Germany
}

\begin{abstract}
Transport mechanism studies in $\mathrm{TiO}_{2} / \mathrm{In}(\mathrm{OH})_{\mathrm{x}} \mathrm{S}_{\mathrm{y}} / \mathrm{Pb}(\mathrm{OH})_{\mathrm{x}} \mathrm{S}_{\mathrm{y}} / \mathrm{PEDOT}$ :PSS eta solar cell have been carried out. The characterizations have been performed both in the dark and under vary ing illu mination intensity for temperature range $200 \mathrm{~K}-320 \mathrm{~K}$. Calculations from ideality factor have shown that the recombination process of the eta solar cell in the dark to be tunneling enhanced, while under illumination it is thermally activated and takes place through exponentially distributed energy recombination levels. The temperature has been found to influence series resistance of the solar cell. Series resistance has been found to be high at low temperature and low at higher temperature, thus we can conclude that the recombination is thermally activated.
\end{abstract}

Keywords Eta Solar Cell, Recombination, Series Resistance, Buffer Layer

\section{Introduction}

The eta solar cell is based on a new concept proposed a few years ago by Prof. Könenkamp group[1,2] and is based on the concept of two types of solar cells: the dye sensitized solar cell model (nanostructured configuration, separation of light absorption from charge transport, and majority carrier type of device) and classical solar cells idea (all solid state, use of inorganic materials)[1, 2, 3, 4]. Dye sensitized solar cell is a majority carrier type of device made up of main ly nanoporous $\mathrm{TiO}_{2}$ thin film which is covered with dye monolayer and then a liquid electrolyte is applied, the front electrode is provided by the $\mathrm{SnO}_{2}: \mathrm{F}$ glass substrate while the counter electrode is made from platinum coated glass [5]. On the other hand, the eta solar cell instead of having a monolayer of dye mo lecule, an extremely thin absorber (eta) material is sandwiched between two wide band gap n- and ptype materials. The eta solar cell is thus a combination of dye sensitized and classical solar cell concepts [6].

A number of devices based on eta concept have been reported with mainly the extremely thin absorber material of choice being CdTe[7], a-Si[8], $\mathrm{CuInS}_{2}[9]$, and $\mathrm{PbS} /$ $\mathrm{Pb}(\mathrm{OH})_{\mathrm{X}} \mathrm{S}_{\mathrm{y}}[10,11]$. Nonetheless, the knowledge about the effect of recombination mechanism on the series resistance in eta solar cell is still limited. In this article, we report on

* Corresponding author:

siafu2001@yahoo.com (Robinson Musembi)

Published online at http://journal.sapub.org/ijee

Copyright (C) 2013 Scientific \& Academic Publishing. All Rights Reserved this subject through characterization of temperature dependence of J-V curves of an highly structured $\mathrm{TiO}_{2} /$ $\mathrm{In}(\mathrm{OH})_{\mathrm{x}} \mathrm{S}_{\mathrm{y}} / \mathrm{Pb}(\mathrm{OH})_{\mathrm{x}} \mathrm{S}_{\mathrm{y}} / \mathrm{PEDOT}: \mathrm{PSS} / \mathrm{Au}$ solar cell at different illumination intensities.

\section{Experimental Method}

The solar cells based on $\mathrm{Pb}(\mathrm{OH})_{\mathrm{x}} \mathrm{S}_{\mathrm{y}}$ eta material were fabricated by the following method: the substrate used was a $15 \Omega / \mathrm{sq}$ sheet resistance $\mathrm{SnO}_{2}: \quad \mathrm{F}$ glass from Förschungszentrum Jülich. The substrate window layer used for our solar cell was $2 \mu \mathrm{m}$ th ick $\mathrm{TiO}_{2}$ thin films deposited by sol-gel technique at SgLux GmbH. The other thin film layers coated were $80 \mathrm{~nm}$ thick indium hydroxyl sulphide, $\mathrm{In}(\mathrm{OH})_{\mathrm{x}} \mathrm{S}_{\mathrm{y}}$, and approximately $10 \mathrm{~nm}$ thick lead hydroxyl sulphide, $\mathrm{Pb}(\mathrm{OH})_{\mathrm{x}} \mathrm{S}_{\mathrm{y}}$, successively by chemical bath deposition method using the following precursors: an aqueous solution containing $0.025 \mathrm{M} \quad \mathrm{InCl}_{3}, 0.1 \mathrm{M}$ thioacetamide, and $0.005 \mathrm{M} \mathrm{HCl}$ was deposited at $70^{\circ} \mathrm{C}$, and the procedure was repeated three times by preparing fresh chemical bath after every 30 minutes, following a similar procedure as described elsewhere $[6,7,11]$ and clearly illustrated in figure 1. Likewise, $\mathrm{Pb}(\mathrm{OH})_{\mathrm{x}} \mathrm{S}_{\mathrm{y}}$ was deposited from an aqueous solution containing $0.05 \mathrm{M} \mathrm{Pb}\left(\mathrm{CH}_{3} \mathrm{OOH}\right)_{2}$, $0.2 \mathrm{M} \mathrm{NaOH}, 0.05 \mathrm{M}$ triethanolamine, and $0.05 \mathrm{M}$ thiourea at $40^{\circ} \mathrm{C}$ for 10 minutes. The last thin film layer to be deposited was an electrically conducting polymer material poly(3,4ethylenedioxythiophene) (PEDOT) doped with water soluble polyelectrolyte known as polystyrene sulfonate acid (PSS), was deposited undiluted by spin coating technique. 


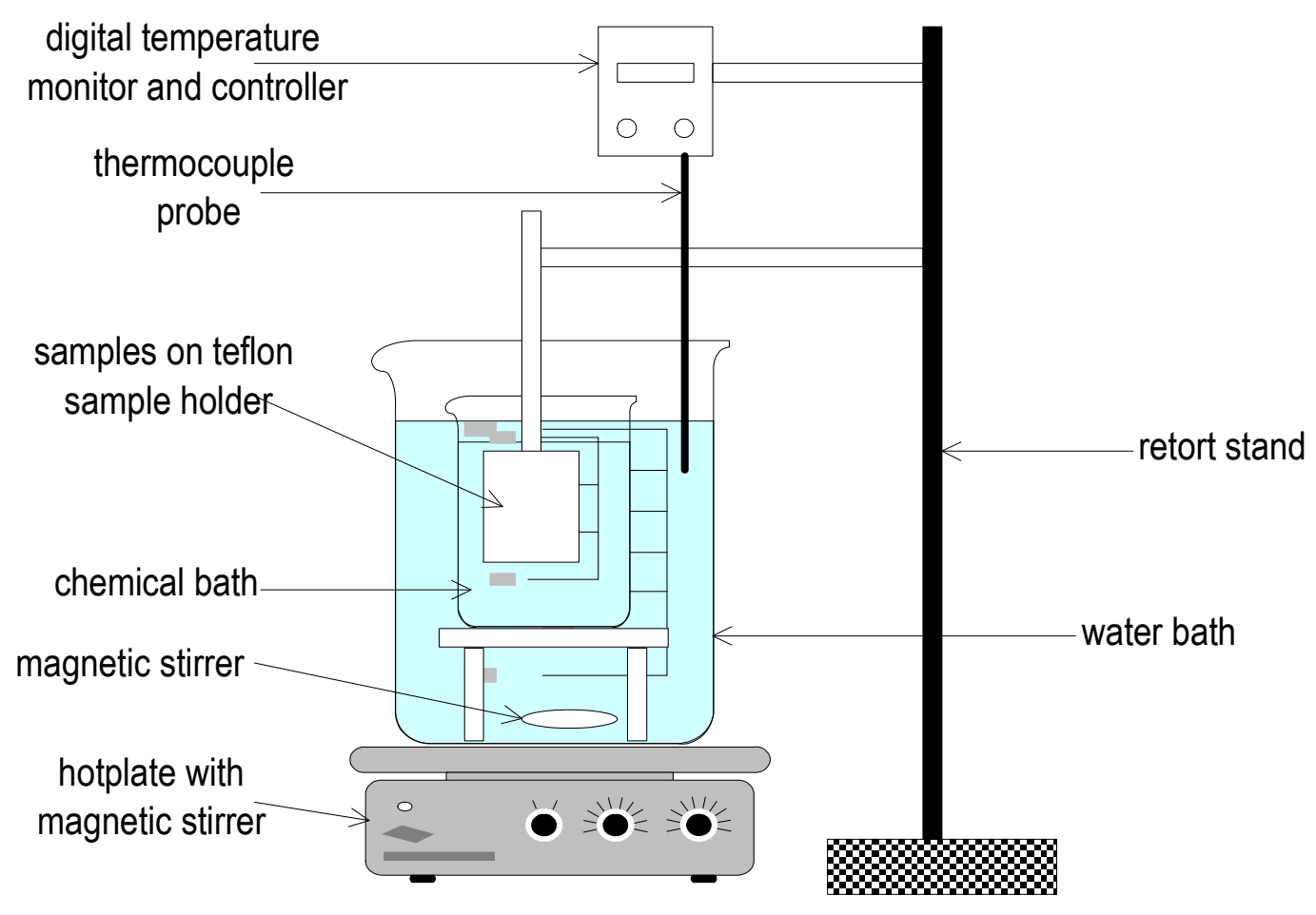

Figure 1. setup for chemical bath deposition used in depositing $\operatorname{In}(\mathrm{OH})_{\mathrm{x}} \mathrm{S}_{\mathrm{y}}$ and $\mathrm{Pb}(\mathrm{OH})_{\mathrm{x}} \mathrm{S}$, respectively

The solar cell was completed by gold back contacts deposited using a specially made mask which gave solar cells of $0.126 \mathrm{~cm}^{2}$ areas $[6,10,11]$.

The temperature dependent current voltage (JV-T) was performed in an evacuated nitrogen cooled cryostat using Keithley 2400 series current voltage source meter. The light source for the solar simu lator was a halogen lamp (General Electric $^{\mathrm{TM}}, 120 \mathrm{~V}, 300 \mathrm{~W}$, model L268) calibrated to 100 $\mathrm{mW} / \mathrm{cm}^{2}=1$ sun at AM 1.5. The following procedure was followed in performing the experiment: the temperature was first lowered to $\mathrm{T}=200 \mathrm{~K}$, and then current voltage measurements were taken beginning with measurements in the dark, followed by 12 successive measurements under illumination. The light intensity was decreased from 100 $\mathrm{mW} / \mathrm{cm}^{2}$ to $0.05 \mathrm{~mW} / \mathrm{cm}^{2}$ by use of neutral density filters. The same procedure was applied for each temperature measurement up to $320 \mathrm{~K}$, the temperature being consecutively changed in steps of $10 \mathrm{~K}$.

\section{Transport Mechanism Theory}

The one diode model developed for polycrystalline heteronjunction thin film solar cell was used for describing and analyzing the JV - T curves of the eta solar cell in the dark and under illumination[12, 13]. The forward current density $\mathrm{J}$ of the heterojunction is described by

$$
\begin{aligned}
J & =J_{o} \exp \left(\frac{q V}{A k T}\right) \\
& =J_{o o} \exp \left(\frac{-E_{a}}{A k T}\right) \exp \left(\frac{q V}{A k T}\right)
\end{aligned}
$$

where $A, J_{o}$ and $k T / q$ are the ideality factor, saturation current density of the diode and the thermal voltage, respectively. The term $J_{o o}$ is the temperature dependent prefactor, while $E_{a}$ is the activation energy of the recombination. Equation 1 can be rearranged to give approximation of open circuit voltage as $[12,13]$

$$
\begin{aligned}
V & \approx \frac{A k T}{q} \ln \left(\frac{J_{s c}}{J_{o}}\right) \\
& =\frac{E_{a}}{q}-\frac{A k T}{q} \ln \left(\frac{J_{o o}}{J_{s c}}\right)
\end{aligned}
$$

where $J_{s c}$ is the short circuit current density. In equation 2, if we assume $A, J_{s c}$ and $J_{o o}$ are independent of $T$, a plot of $V_{o c}$ as a function of $T$ should yield a straight line and the extrapolation to $T=0 \mathrm{~K}$ gives the activation energy $E_{a}$. However when tunneling process is significant, equation 2 can be reorganized to give[12, 13]

$$
A \ln J_{o}=-\frac{E_{a}}{k T}+A \ln J_{o o}
$$

A plot of the corrected saturation current density $A \ln J_{o}$ as a function of the inverse temperature $1 / T$ will yield a straight line with a slope giving us a precise value of activation energy $E_{a}$. The value of activation energy can guide us in deducing the type of recombination process taking place in a solar cell device: when $E_{a}=E_{g}$ (where 
$E_{g}$ is the band gap energy) will indicate that recombination is taking place in the bulk of the materials absorber, or interface recombination is dominant when $E_{a}=E_{g}[12,13]$.

\section{Results and Discussion}

The solar cell structure based on the novel eta concept studied in this work is shown in figure 2.

The extremely thin absorber material made of $\mathrm{Pb}(\mathrm{OH})_{\mathrm{x}} \mathrm{S}_{\mathrm{y}}$ is sandwiched between two large bandgap materials, one n-type $\left(\mathrm{TiO}_{2}\right)$ and the other p-type (PEDOT:PSS), the bandgaps of the two semiconductors are $3.2 \mathrm{eV}[10,11]$ and $2.0 \mathrm{eV}[16]$, respectively. The solar cell is completed with $\mathrm{Au}$ back contact with front contact being provided by $\mathrm{SnO}_{2}: \mathrm{F}$ layer or a thin film of gold on the glass substrate. The graph shown in figure 3 is for a solar cell without a buffer layer, the $\mathrm{J}-\mathrm{V}$ curve under illumination is almost ohmic, showing that there is a lot of interface recombination taking place between $\mathrm{TiO}_{2} / \mathrm{Pb}(\mathrm{OH})_{\mathrm{x}} \mathrm{S}_{\mathrm{y}}$, the conversion efficiency is observed to be around $0.01 \%$, consequently there is a need for a buffer layer of a material compatible with $\mathrm{TiO}_{2}$ and $\mathrm{Pb}(\mathrm{OH})_{\mathrm{x}} \mathrm{S}_{\mathrm{y}}$ in order to mitigate the loss of charge carriers.

The material chosen for this purpose is $\operatorname{In}(\mathrm{OH})_{\mathrm{x}} \mathrm{S}_{\mathrm{y}}$, its suitability as a buffer layer is well described in the literature $[16,17]$. The as prepared solar cell after inserting the buffer layer, the current density-voltage characteristics do not display a good conversion efficiency, this is as shown in figure 4 where an efficiency of $0.07 \%$ was realized, The other solar cell parameters were current density $0.7 \mathrm{~mA} / \mathrm{cm}^{2}$, open circuit voltage $\mathrm{V}_{\mathrm{oc}}=308 \mathrm{mV}$ and fill factor of 0.3021 .

After annealing the buffer layer at $300^{\circ} \mathrm{C}$ for 30 minutes, the solar cell shows tremendous improvement in terms of the overall conversion efficiency. The changes observed in the conversion efficiency of the solar cell after annealing can be attributed to two changes which occur in the buffer layer: the material changes from amorphous state to crystalline state and also becomes slightly rich in $\mathrm{In}_{2} \mathrm{~S}_{3}$ content, this is well described in the literature by Bayon, et. al.,[18,19] and Kumaresan et. al.,[20]. The solar cell which demonstrated the best efficiency after annealing the buffer layer was chosen for transport mechanism studies.

The solar cell analyzed for current generation and recombination properties had a structure of the type $\mathrm{TiO}_{2} / \mathrm{In}(\mathrm{OH})_{\mathrm{x}} \mathrm{S}_{\mathrm{y}} / \mathrm{Pb}(\mathrm{OH})_{\mathrm{x}} \mathrm{S}_{\mathrm{y}} / \mathrm{PEDOT}$ :PSS/Au eta solar cell, which under AM 1.5 conditions had the following parameters: open circu it voltage $\mathrm{V}_{\mathrm{oc}}=0.249 \mathrm{~V}$, short circu it current density $\mathrm{J}_{\mathrm{sc}}=9.24 \mathrm{~mA} / \mathrm{cm}^{2}$, fill factor of 0.34 , and finally the overall conversion efficiency of $0.78 \%$.

The current density - voltage data for the $\mathrm{TiO}_{2} /$ $\mathrm{In}(\mathrm{OH})_{\mathrm{x}} \mathrm{S}_{\mathrm{y}} / \mathrm{Pb}(\mathrm{OH})_{\mathrm{x}} \mathrm{S}_{\mathrm{y}} / \mathrm{PEDOT}$ : PSS/Au eta solar cells was measured as a function of temperature from $200 \mathrm{~K}$ to $320 \mathrm{~K}$, and at different light intensities, thereafter valuable data was then extracted for further analysis.

Figure 5 shows the temperature dependency of conversion efficiency of the $\operatorname{In}(\mathrm{OH})_{\mathrm{x}} \mathrm{S}_{\mathrm{y}}$ modified eta solar cell. The conversion efficiency is observed to vary inversely with temperature at different illumination intensities. The results shows that temperature and illumination intensity have strong influence on the conversion efficiency of the eta solar cell with the highest values being observed at low temperature of $200 \mathrm{~K}$, the conversion efficiency is observed to be increasing fro $\mathrm{m} 0.54 \%$ to $0.85 \%$.

Using models described in section 3 and in further details as reported els ewhere[6,13], equation 2 , can be used to fit open circuit voltage as a function of temperature to the plot of illumination intensity dependent $V_{o c}$ versus $T$ and assuming that $A, J_{s c}$ and $J_{o o}$ are independent of temperature, a linear extrapolation to $T=0 \mathrm{~K}$ gives an activation energy $E_{a}=0.79 \mathrm{eV}$, this is shown in figure 6 . According to work done by Bayon, et. al.,[10, 11], the activation energy value is close to the chemical bath deposited $\mathrm{Pb}(\mathrm{OH})_{\mathrm{x}} \mathrm{S}_{\mathrm{y}}$ band gap, $E_{a}=0.85 \mathrm{eV}$. From this analysis, it follows that $E_{a} \approx E_{g}$ indicating that recomb ination mechanis $m$ in this type of device takes place in the bulk of the absorber material, also, it can be deduced that the band gap of the chemical bath deposited $\mathrm{Pb}(\mathrm{OH})_{\mathrm{x}} \mathrm{S}_{\mathrm{y}}$ can be engineered for further widening. These results corroborate earlier findings by Koenenkamp and Hoyer[13].

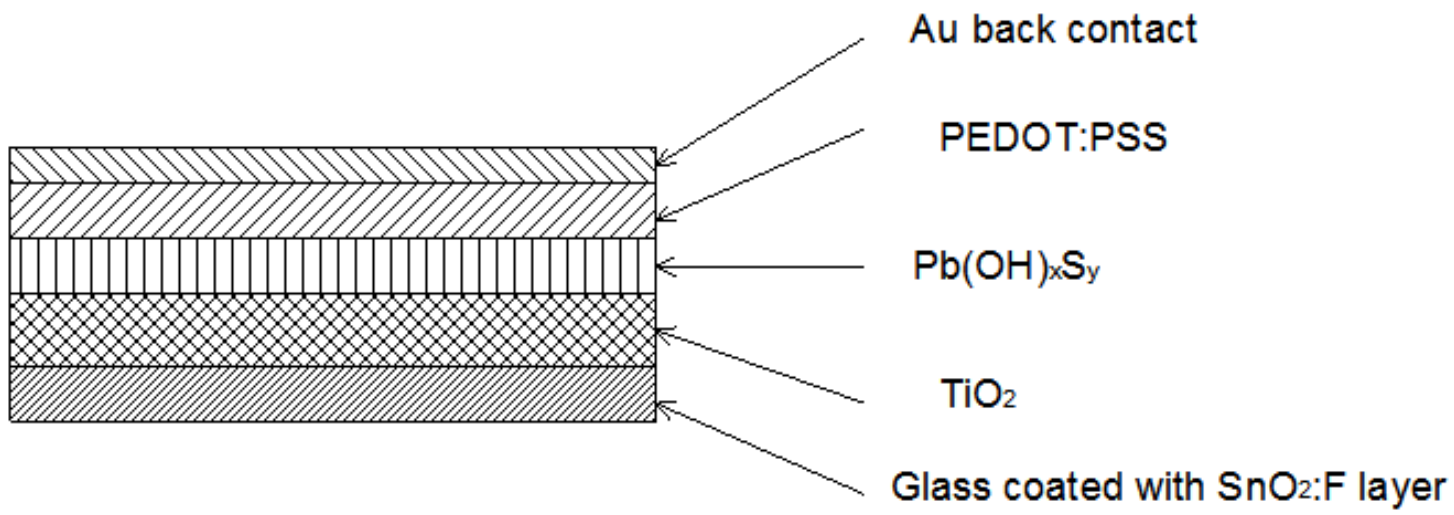

Figure 2. The structure of the eta solar cell fabricated and studied in this work 


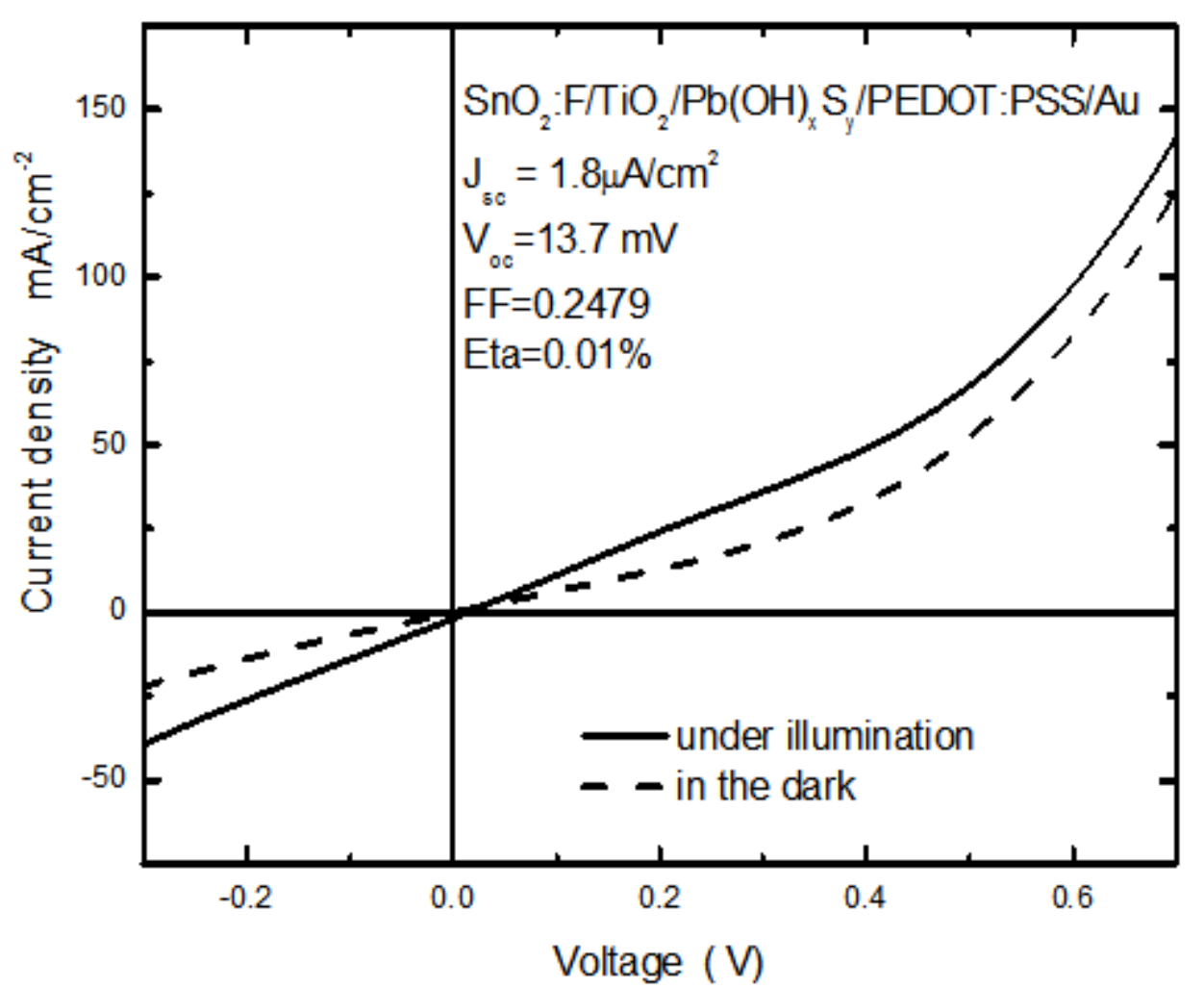

Figure 3. The current density - voltage charact eristics for the solar cell structure shown in figure 1

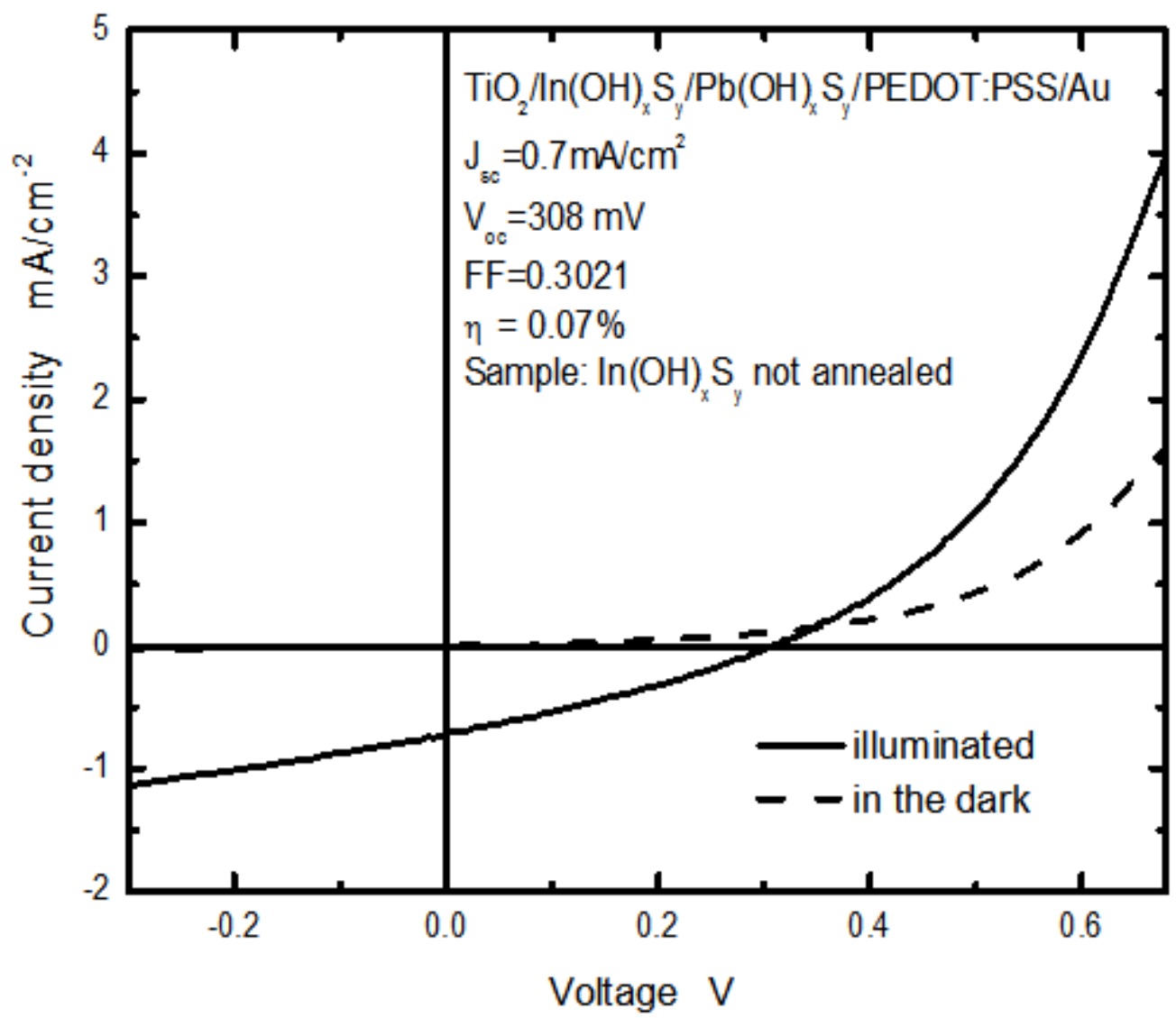

Figure 4. The current density - voltage characteristics for the solar cell with a buffer layer of $\operatorname{In}(\mathrm{OH}) \mathrm{xSy}$ 


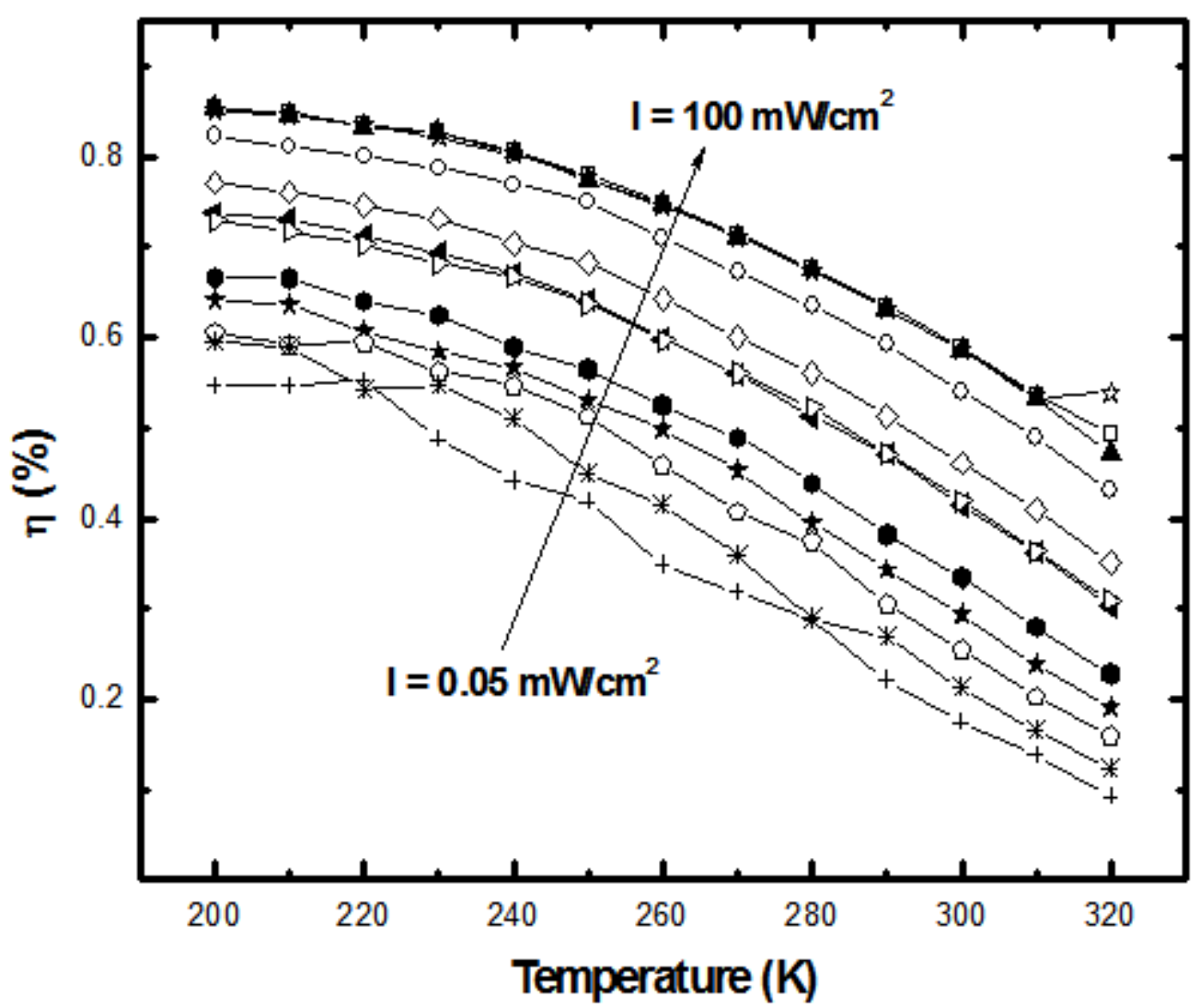

Figure 5. temperature dependency of conversion efficiency at different illumination int ensities $\mathrm{I}=0.05 \mathrm{~mW} / \mathrm{cm}^{2}-100 \mathrm{~mW} / \mathrm{cm}^{2}$

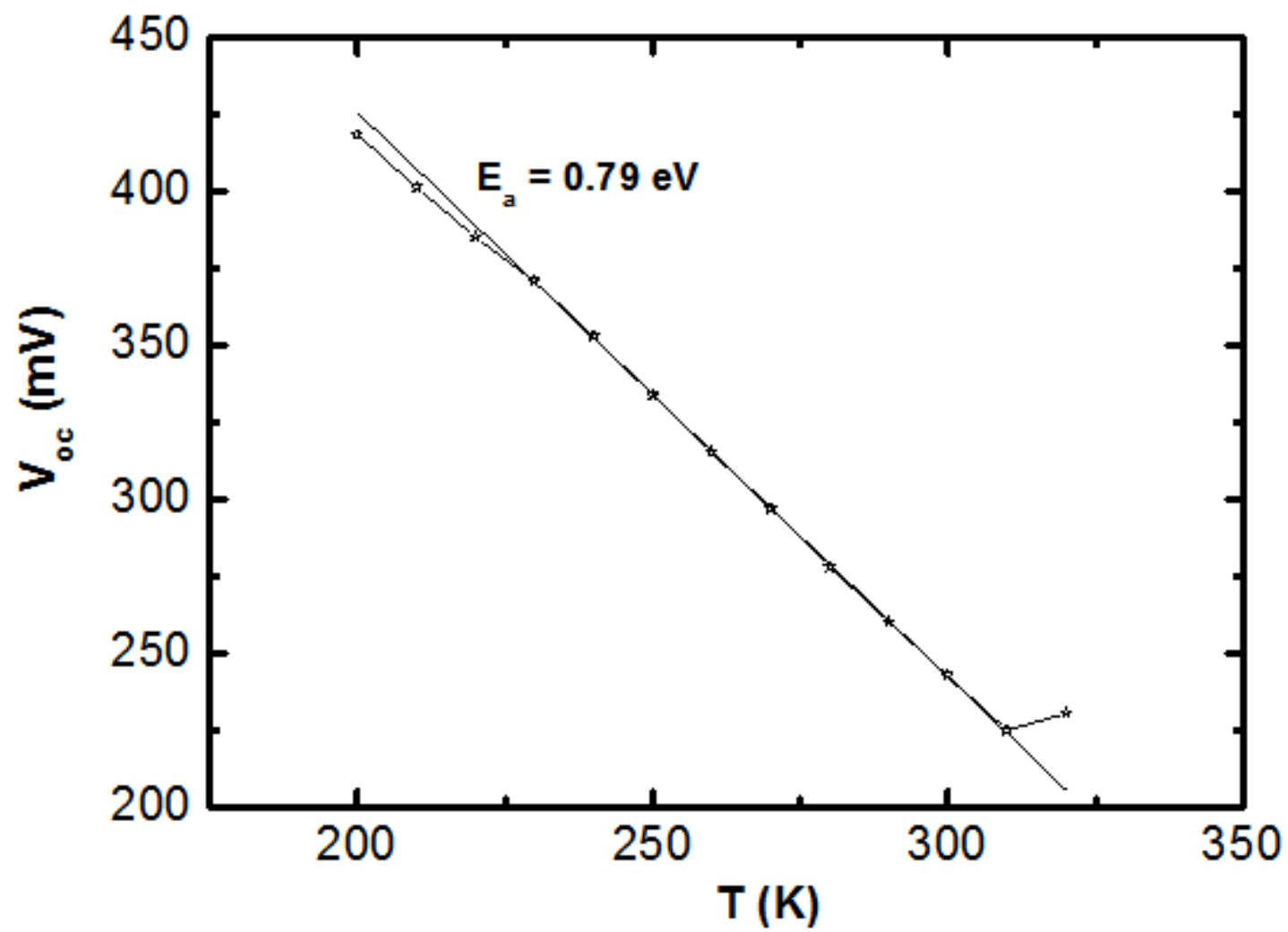

Figure 6. activation enrgy of recombination derived from open circuit voltage $\mathrm{U}_{\mathrm{oc}}$ as a function of temperature 


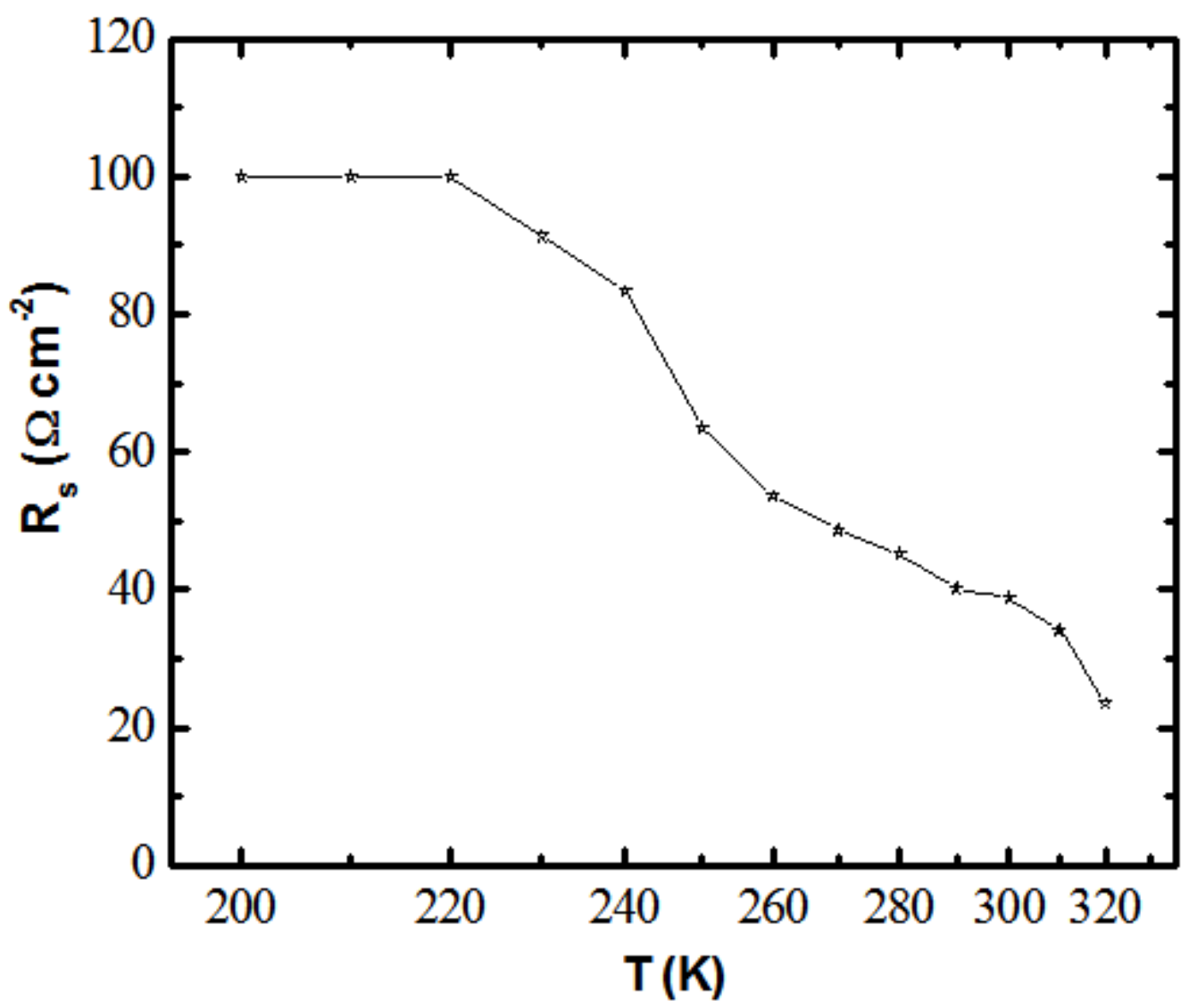

Figure 7. Temperat ure dependence of series resistance of eta solar as extracted from temperat ure dependent current density-voltage data

Figure 7 shows temperature dependence of series resistance of the eta solar cell. The result shows that the eta solar cell had high resistance when it is operated at low temperature environ ment than when the temperature is raised to above the room temperature. The behaviour of the series resistance can be attributed to the number of available charge carriers in the solar cell. Since the series resistance is decreasing with temperature it can be deduced that recombination in the eta solar cell is thermally activated process at high temperature and tunneling assisted process at lower temperatures.

The deduction from the series resistance behaviour is corroborated by similar work reported elsewhere[6,13]. Using equation 3 , calcu lations show that the ideality factor of the eta solar cell is observed to decrease with increasing temperature. In the dark the ideality factor is given by $6.9 \leq A \leq 10.1$, while under illumination it is given by $1.2 \leq A \leq 1.6$. The temperature behaviour of the ideality factor in the dark indicates that recombination mechanism of eta solar cell is do minated by tunneling process while under illumination the charge carrier recombination is thermally activated since there is observed temperature dependence[6, 13]. It can also be deduced from the observation that ideality factor decreases as the temperature increases from 1.6 at $200 \mathrm{~K}$ to 1.2 at $320 \mathrm{~K}$ showing that recombination occurs through exponentially distributed energy recombination levels. The values of ideality factor at high temperature under illumination shows the recombination occurs through shallow levels, while at low temperatures deep levels are involved in the recombination as reported in literature[13].

\section{Conclusions}

Operation temperature of the $\mathrm{TiO}_{2} / \mathrm{In}(\mathrm{OH})_{\mathrm{x}} \mathrm{S}_{\mathrm{y}} / \mathrm{Pb}(\mathrm{OH})_{\mathrm{x}}$ $\mathrm{S}_{\mathrm{y}} / \mathrm{PEDOT}$ : PSS solar cell has been found to strongly influence the conversion efficiency of the eta solar cell. Analysis of the ideality factor shows that recombination is tunneling enhanced dominated process when the solar cell is operated in the dark while under illumination it is thermally activated and takes place in the bulk of the absorber material at high temperatures, but at low temperature it takes place in the shallow levels. The parasitic series resistance has been observed to vary with temperature, it is highest at low temperature of a round $200 \mathrm{~K}$ and lo west when temperature is elevated to $320 \mathrm{~K}$, this shows that the recombination is a thermally activated process and strongly influences series resistance of the solar cell.

\section{ACKNOWLEDGEMENTS}

RM would like to thank the group of Organic materials at Helmholtz-Zentrum for financial support, also thanked for financial support are IPPS Sweden and the University of Nairobi, Kenya. 


\section{REFERENCES}

[1] S. Siebentritt, K. Ernst, C-H. Fischer, R. Koenenkamp, and M. Ch. Lux-Steiner, (1997), CdTe and CdS as extremely thin absorber material in an eta solar cell Proc. $14^{\text {th }}$ Eur. Photovoltaic Solar Energy Conf. Exhib., Barcelona, Spain, p. 1823.

[2] I. Kaiser, K. Ersnt, C-H. Fischer, R. Koenenkamp, C. Rost, I. Sieber, and M. Ch. Lux-Steiner, (2001), The eta solar cell with $\mathrm{CuInS}_{2}$ : A photovoltaic cell concept using an extremely thin absorber (eta), Sol. Energy Mater. \& Sol. Cells 67, 89-96.

[3] G. Larramona, C. Chone, A. Jacob, D. Sakakura, B. Delatouche, D. Pere, X. Cieren, M. Nagina, and R. Bayon, 2006, Nanostructured Photovoltaic Cell of the Type Titanium Dioxide, Cadmium Sulfide Thin Coating, and Copper Thiocyanate Showing High quantum Efficiency, Chem. Mater. 18, 1688-1696.

[4] Erki Karber, Aimi Abass, Samira Khelifi, Marc Burgelman, Atanas Katerski, Malle Krunks, 2013, Electrical Characterization of All layer spray ed solar cell based on $\mathrm{ZnO}$ nanorods and extremely thin CIS absorber, Solar Energy, 91, 48-58.

[5] B. O'Regan and M. Gratzel, (1990), A low cost high efficiency solar cell based on dye sensitized colloidal TiO2 films Nature, 353, 737-739.

[6] R.J. Musembi, M. Rusu, J.M. Mwabora, B.O. Aduda, K. Fostiropoulos, and M. Ch. Lux-Steiner,(2008), Intensity and temperature characterization of eta solar cell, Physica Status Solidi, 205 (7), 1713-1718.

[7] K. Ernst, R. En gelhardt, K. Ellmer, C. Kelch, H. J. Muffler, M. Ch. Lux-Steiner, and R. Koenenkamp,(2006), Contacts to a solar cell with extremely thin CdTe absorber, Thin Solid Films, 387, 26-28.

[8] A. Wahi and R. Koenenkamp,(1992), Proc. $11^{\text {th }}$ Photovoltaic Solar Energy Conf., Montreux, Switzerland, 714.

[9] I. Kaiser, K. Ernst, C-H. Fischer, C. Rost, I. Sieber, M.Ch Lux-Steiner, and R. Koenenkamp, (2001), The eta solar cell with $\mathrm{CuInS}_{2}$ : A photovoltaic cell concept using an extremely thin absorber (eta), Sol. Energy Mater. \& Sol. Cells, 67, 89-96.

[10] R. Bayon, R. Musembi, A. Belaidi, M. Bär, T. Guminskaya, M. Ch. Lux-Steiner, and T. Dittrich,(2005), Highly structured
$\mathrm{TiO}_{2} / \mathrm{In}(\mathrm{OH})_{\mathrm{x}} \mathrm{S}_{\mathrm{y}} / \mathrm{PbS} / \mathrm{PEDOT}$ : PSS for photovoltaic applications Sol. Energy, Mater. \& Sol. Cells, 89, 13-25.

[11] R. Bayon, R. Musembi, A. Belaidi, M. Bär, T. Guminskaya, M. Ch. Lux-Steiner, and T. Dittrich, (2005), Highly structured $\mathrm{TiO}_{2} / \mathrm{In}(\mathrm{OH})_{\mathrm{x}} \mathrm{S}_{\mathrm{y}} / \mathrm{PbS} / \mathrm{PEDOT}$ :PSS to be used in photovoltaic applications, Comptes Rendus Chimie, 9, 730-734.

[12] V. Nadenau, U. Rau, and A. Jasenek, (2000), Electronic properties of $\mathrm{CuGaSe}_{2}$-based heteronjuction solar cells, J. Appl. Phys., 87, 584-593.

[13] M. Rusu, W. Eisele, R. Wurz, A. Ennaoui, M. Ch. Lux-Steiner, T.P. Niesen, and F. Karg, (2003), Current transport in $\mathrm{ZnO} / \mathrm{ZnS} / \mathrm{Cu}(\mathrm{In}, \mathrm{Ga})(\mathrm{S}, \mathrm{Se})_{2}$ solar cell, J. Phys. Chem. Solids, 64, 2037-2040.

[14] R. Könenkamp and P. Hoyer, (1995), Photoconduction in porous $\mathrm{TiO}_{2}$ sensitized by PbS quantum dots, Appl. Phys. Letter, 66(3), 349-351.

[15] M.Y. Song, K.J. Kim and D.Y. Kim, (2005), Enhancement of photovoltaic characteristics using a PEDOT interlayer in TiO2MEHPPV heteronjunction devices, Solar Energy Materials and Solar Cells, 85 (1), 31-39.

[16] C. Kaufmann, R. Bayon, W. Bohne, J. Rohrich, R. Klenk, P.J. Dobson,(2002), Chemical bath deposition of indium oxyhydroxy sulfide thin films: effect of the bath on thin film composition, J. Electrochem. Soc. 149(1), C1-C9.

[17] T. Dedova, J. Wienke, M. Goris, M. Krunks, (2007), Characterization of the chemical bath deposited $\operatorname{In}(\mathrm{OH})_{\mathrm{x}} \mathrm{S}$, films: effect of the growth conditions, Thin Solid Films, 515(15), 6064-6067.

[18] R. Bayon and J. Herrero, (2000), Structure and morphology of the indium hydroxyl sulphide thin films, Applied Surface Science, 158 (1-2), $49-57$.

[19] R. Bayon, C. Guillen, M.A. Martinez, M.T. Gutierrez and J. Herrero, (1998), Preparation of indium hydroxyl sulfide $\operatorname{Inx}(\mathrm{OH}) x$ Sy thin film by chemical bath deposition, Journal of Electrochemical Society, 145 (8), 2775 - 2779.

[20] R. Kumaresan, M. Ichimura, N. Sato and P. Ramasamy, (2002), Application of novel photochemical deposition technique for the deposition of indium sulfide, 96 (1), $37-42$. 